UDC $355.02-055.2(457)$

DOI: https://doi.org/10.30839/2072-7941.2018.149654

\title{
GENDER APPROACH AND DEMOCRATIC VALUES IN THE CONTEXT OF THE MODERN GENERATION OF MILITARY STAFF'S MENTALITY SHAPING
}

\author{
(C) KRYMETS, L. V. \\ National Defense University of Ukraine named after Ivan Chernyakhovskyi (Kyiv, \\ Ukraine) \\ E-mail: Liudmylakrymets@ gmail.com, ORCID 0000-0001-7451-5208
}

Actuality. Modern Ukrainian society puts forward a set of professional and moral-ethical requirements for both individual servicemen and the system of military training in general. In this regard, there is a need for the preparation of qualitatively new management personnel for the military administration, headquarters, and structures for the moral and psychological support of all levels. That must be done in order to implement a significant range of socio-political and military reforms in order to democratize and optimize the Ukrainian army, taking into account both the best national, and the leading world experience.

The purpose of article is emphasizing of gender approach and definition the completely term of modern military personnel mentality and demonstration of some peculiarities of mentality shaping process in the Armed Forces of Ukraine. The methodological base of research are general scientific principles of integrity, objectivity and historicity, which allowed to reveal the specifics of the formation of the mental culture of servicemen in the process of practical training. Scientific novelty. According the author's conception mentality of a serviceman is a dynamically developing system in which the unification of not only personal experience but also professional development takes place. The mentality of the servicemen of the Armed Forces of Ukraine and other components of the defense forces is an integrative professionally determined sociocultural property that determines the specifics of their worldview, the way of thinking, the peculiarities of the formation of collective and individual consciousness and professional behavior.Gender mentality is a socio-ethical component of the mentality of a serviceman that reveals the specifics of gender stereotypes and the way of thinking that in the conditions of the reformation and development of the Armed Forces of Ukraine should be based on democratic values. Conclusion. This article will help you understand what democratic values form the ethical basis for the formation of a modern Ukrainian army that will meet the requirements of the time and will reveal the specificity of the gender mentality of the servicemen.

Key words: mentality of servicemen of the Armed Forces of Ukraine, gender mentality, axiological aspects of the formation of mentality, ethical code, European values, social philosophy, military management.

Actuality. Ukraine is a young, democratic, law-governed state of witch people have demonstrated their active social position on the wave of national upsurge. In the face of the complex challenges of our time, it became clear that the role of the army as a guarantor of a state security, as a pledge of sustainable development of society, is extremely high.
Our country pays a prohibitively high price for reducing the attention to the army in recent decades and seeks to improve the quality of preparation for a conscious and devoted defense of the state of a new generation of servicemen whose responsibility to the country, in front of every citizen of our country, is invariably increasing. 
Modern Ukrainian society puts forward a set of professional and moral-ethical requirements for both individual servicemen and the system of military education and training in general. In this regard, there is a need for the preparation of qualitatively new management personnel for the military administration, headquarters, and structures for the moral and psychological support of all levels. That must be done in order to implement a significant range of socio-political and military reforms in order to democratize and optimize the Ukrainian army, taking into account both the best national, and the leading world experience.

This article will help you understand what democratic values form the ethical basis for the formation of a modern Ukrainian army that will meet the requirements of the time and will reveal the specificity of the gender mentality of the servicemen.

The purpose of the article is to determine gender aspects and the term of military personnel mentality and to demonstrate some peculiarities of the mentality shaping process in the Armed Forces of Ukraine.

The methodological base of research are general scientific principles of integrity, objectivity and historicity, which allowed to reveal the specifics of the formation of the mental culture of servicemen in the process of practical training. The author proceeds from the standpoint of the socio-cultural approach that changing the external environment, the environment inevitably entails changes in the inner world of personality, personality entities, that is, the change in the motivational and value sphere of the individual under the influence of socio-cultural factors leads to a transformation of mentality.

Analysis of recent researches and publications. The study of mentality is one of the fundamental tasks in both philosophical and psychological researchers. The significance of the study of this problem is related to the analysis of the sources of human behavior, with the way of human perception of objective reality. The field of study of mentality includes a wide range of theoretical studies at the junction of various humanities disciplines. At the same time, the analytical review of literature revealed in the studies the lack of a single understanding of the term "mentality", as well as the holistic mechanism of its shaping and dynamics of development [1, 2, 3, 4].

Modern philosophic dictionaries define the concept of mentality as the spiritual mood of an individual or society, which determines worldview and world attitudes and determines the unity of cultural traditions. As complex and contradictory interaction of installations, stereotypes, mental and figurative complexes that are in the collective unconscious, with archetypes of culture [5].

Presentation of main material. Modern changes in socio-political, socio-cultural and economic situation in Ukraine have also led to the transformation of the way of perceiving the surrounding reality and some change of mentality of Ukrainians. The dialectic of the sustainability and variability of mental forms, the complex nature of their formation deserve special attention in 
the current transitional era, since they largely determine the direction of evolutionary changes in the mass consciousness, the effectiveness of the mechanisms of adaptation of large social communities to the changing conditions of social development.

The problem of studying mentality on the way to implementation of a significant range of modern democratic reforms has been actualized in Ukrainian society. It takes place since the formation and actualization in society of certain values, values orientations, which is the basis of the formation of mentality, can determine perception or rejection at the level of consciousness of the individual, not only the reforms themselves, but also to be an obstacle to the social development of the country.

The appeal of science to qualitatively new, motivational and value characteristics of mentality is due, in our opinion, to the understanding of man as a goal, and not a means of social development. Return to such determinants of personality development such as: spirituality, impartiality, responsibility promotes the development of individual mentality, qualitatively different from the collective. The change in the motivational-value content of the mentality of the younger generation of Ukrainians is aimed at the formation of both, personal internal regulation of behavior and external regulation.

According the author's conception mentality of a serviceman is a dynamically developing system in which the unification of not only personal experience but also professional development takes place. The mentality of the servicemen of the Armed Forces of Ukraine and other components of the defense forces is an integrative professionally determined sociocultural property that determines the specifics of their worldview, the way of thinking, the peculiarities of the formation of collective and individual consciousness and professional behavior.

It should be noted separately that the analysis of socio-psychological processes that accompany the course of political and economic transformations in modern Ukraine shows that in the public consciousness there are gender transformations in the structure of mentality characteristic of the turning points of historical development. Gender transformations in the structure of mentality - a process of gender changes in value representations, socio-psychological settings and gender stereotypes about sex-role behavior that will determine the face of the future society.

The study of gender transformations in the structure of the mentality of servicemen of the Armed Forces of Ukraine is particularly relevant. Such studies are of obvious practical importance, they will create the necessary basis for the implementation of a significant range of democratic reforms, will allow timely impact on social processes, resolve conflicts and controversies in the military-professional environment.

Gender mentality is a socio-ethical component of the mentality of a serviceman that reveals the specifics 
of gender stereotypes and the way of thinking that in the conditions of the reformation and development of the Armed Forces of Ukraine should be based on democratic values.

In the Armed Forces of Ukraine has been initiated of the implementation of the NATO Directives to the educational process, including 2017: BI-Strategic Command Directive (BI-SCD) 040001 (INTEGRATING UNSCR 1325 AND GENDER PERSPECTIVE INTO THE NATO COMMAND STRUCTURE), which will allow to raise the quality of professional training of military specialists [7].

According to the directive, GENDER means a set of social attributes that are formed in the process of socialization and manifested in the interaction between men and women. Gender determines the personal position of bearers of gender mentality and their value in a social context. Gender also means relationships between men, women, boys and girls, as well as relationships between women and men. It is noteworthy that the concept GENDER, according to the BIStrategic Command Directive (BISCD) 040-001, does not direct the exclusive focus of attention exclusively to women.

Gender integration is the basis for gender mainstreaming and is defined as a strategy used to achieve gender equality in the armed forces by enhancing the attraction of women and men to mission assignments at all levels, in order to take into account the interests and experience of both sexes. The assessment of gender mainstreaming aims at identifying gender-specific differences in social and professional development and attitudes towards women and men in the defined context reflected in their social roles and interactions, in the division of labor, authority and access to resources. Gender mainstreaming is one of the priority goals of the military reform of the Armed Forces of Ukraine.

For the formation of gender mentality in the context of the Armed Forces of Ukraine it is necessary to use a number of initiatives in the field of military education and science, with the mandatory inclusion of monitoring mechanisms. According to international standards, the personnel of the armed forces should be trained in the field of human rights, gender equality in accordance with their responsibilities, as well as training on gender issues.

At the same time, it's important to keep in mind that the Code of Conduct states that the North Atlantic Alliance (NATO) envisages promoting the highest level of trust among its members and requiring them integrity, impartiality, loyalty, accountability and professionalism. These five core semotactical values form the axiological basis of the Ethical Code, which defines the requirements for the conduct of all civilian and military personnel and NATO units [6].

Integrity, impartiality, loyalty, accountability and professionalism are fundamental democratic values to be reflected in the Statute of the internal service of the Armed Forces of Ukraine, the text of the Military Oath, taking into account national peculiarities of the formation of the 
mentality of servicemen of the Armed Forces of Ukraine.

According to ethic standards of The NATO Code of Conduct, Integrity should be implemented such way. As NATO staff, we are committed to maintaining the highest standards of professional and personal conduct in such a way as to uphold the trust and confidence of the citizens of all our member states. As such, we affirm that we

- Are honest and truthful in our dealings; fully presenting all facts in an unbiased and clear manner.

- Avoid situations that might result in real, perceived, or potential conflicts between our personal interests and those of the Alliance.

- Take prompt action to remove ourselves from situations where conflicts of interest can or have occurred.

- Do not use non-public information obtained through our official position for private gain, either for ourselves or others.

- Avoid actions that could be perceived as an abuse of the privileges and immunities conferred on the Organization and its staff.

Loyalty means next points.

As NATO staff, we are faithful and true to the enduring role of the Alliance, the principle of unity upon which it was founded, and in support of the current and future challenges, it faces. As such, we affirm that we

- Support the principles upon which the Alliance was founded.

- Demonstrate a unity of purpose focused on the goals and objectives of the organization.
- Strive to make a personal contribution to NATO's success and foster a culture of results across the Alliance.

- Always put the interests of the organization above our own and that of our individual nations, mindful of all applicable laws and regulations.

- Contribute to the development and maintenance of a positive team spirit.

Accountability is responsibility of staff members. As NATO staff, we are responsible and accountable for our actions and decisions, or failure to act, and accept the consequences of their outcomes. As such, we affirm that we...

- Are transparent in all we do, even when it does not reflect favorably upon us.

- Take full responsibility for our actions and take prompt action to resolve or correct any errors or omissions that we may make.

- Are mindful of the consequences of our actions and decisions before we take them.

- Stay vigilant to any fraud, waste, and abuse that may occur within the organization and address them appropriately.

- Avoid any action that could lead to damage or risk to the Organization or its Communication and Information Systems (CIS) or inappropriate disclosure of NATO information.

Impartiality is neutrality of staff position.

As NATO staff, we serve the Alliance's interest above our personal interests. As such, we affirm that we

- Maintain our objectivity and independence in our professional 
dealings, striving to be fair, just, and equitable in all our activities.

- Keep an international outlook and base our recommendations and decisions on what is best for the Alliance as a whole, rather than the views or interests of our own, or any particular nation or nations.

- Do not accept gifts that might compromise our impartiality or give rise to the perception of a lack of impartiality in the conduct of our official duties.

- Do not engage in unauthorized outside employment or other off-duty activities that might conflict with or otherwise call into question the performance of our official duties.

- Do not use our NATO position or proprietary information to unfairly secure future employment and will not use privileged information to unfair advantage after our NATO employment.

Professionalism is a main staff quality issues.

As NATO staff, we are professionals who are entrusted to carry out our duties to the utmost of our abilities for the common good. As such, we affirm that we

- Put forth an honest effort in the daily performance of our duties.

- Maintain the highest level of competence in our assigned areas and strive for continuous improvement of our knowledge, skills, and abilities.

- Care for and use prudently the limited resources of our organization.

- Protect the security and confidentiality of information entrusted to us.

- Participate in maintaining the safety and security of our information and our workplace.
- Take into consideration the effects of our work on the natural environment.

- Respect the privacy and diversity of our fellow staff members.

- Do not harass or discriminate against others in our workplace, and do not tolerate those who do.

- If supervisors, provide fair leadership and take responsibility for the actions or inactions of our subordinates, ensuring they provide NATO with the best possible service by encouraging and rewarding those who perform well, while correcting those who fail to live up to standards [6].

Taking into account the previously mentioned, articulation in the legal field and the introduction of such European values as professional training of service members of the Armed Forces of Ukraine such as integrity, loyalty, accountability, impartiality and professionalism, will allow forming a legal basis for purposeful influence on their consciousness, beliefs and professional behavior. With the purpose of forming their proper moral and psychological state, as well as the ability to perform assignments for appointment and participation in conducting joint battles operations (operations) with NATO units.

It should be emphasized that in the military sphere the essence of the problem situation is the decline of the classical paradigms of warfare, the need for comprehension and resolution of which involves addressing the philosophical foundations of military science, updating the conceptual foundations of the training of military specialists. 
The tasks facing the military theory and practice in connection with the transformations of both the sociopolitical situation in Ukraine and the armed struggle in the world are of a conceptual nature, since their solution involves changing the ways of thinking and acting within the framework of military policy and military affairs.

In the case of solving the abovementioned tasks concerning the formation of the mentality of servicemen of Ukraine on the basis of democratic principles, science and education systems play a key role. World experience shows that the competitiveness of the country is directly dependent on the competitiveness of science and education [1]. In the knowledge society, the image of science and education undergoes significant transformations. They become the basic foundation of society, turn into an integral part of the human way of life and are mainly pragmatic in nature.

There is no exception to the system of military education and science. The teaching staff of the higher military educational institutions of Ukraine do a common work on the theoretical support for the development of domestic military culture, the overcoming of inertia in methodological foundations and styles of reasoning in military knowledge. It has a crucial role in the struggle for the subjectivity of the Ukrainian nation, the sovereignty and territorial integrity of the Ukrainian state against the backdrop of a continuing war.
We have to add some points about gender training of military staff. As an any training, the gender training of military personnel should to identify the necessary qualifications and monitor the achievements and compliance with the required training standards. Undoubtedly, the superior command not only bears the main responsibility for the integration of gender aspects and the shaping of gender mentality, but also can seriously affect the general and individual approaches to addressing the gender issue, demonstrating this by their own behavior.

It is imperative that the military commanders and bosses seek to develop their own gender-specific skills at all levels of command of the armed forces. However, it is often difficult for them to allocate time for serious training aimed at achieving a deeper understanding of gender equality. In this regard, alternative approaches to the development of their potential can be applied, such as instructor training and mentoring.

Summarizing the abovementioned material, the author can conclude that a democratic society should provide all its citizens, irrespective of gender, equal opportunities to participate in all spheres of public life, including in the protection of the state and the peacemaking process. Mentality of military staff is a dynamically developing system in which the unification of not only personal experience but also professional development takes place. The mentality of the servicemen of the Armed Forces of Ukraine and other 
components of the defense forces is an integrative professionally determined sociocultural property that determines the specifics of their worldview, the way of thinking, the peculiarities of the formation of collective and individual consciousness and professional behavior.

Gender mentality is a socio-ethical component of the mentality of servicemen that reveals the specifics of gender stereotypes and the way of thinking that in the conditions of the reformation and development of the Armed Forces of Ukraine should be based on democratic values. Shaping of gender mentality on the basis of democratic values and achievement of gender parity in the security and defense sector will have a significant impact primarily on the development of Ukrainian society, as well as on enhancement of the professional culture of mutual relations in the military sphere. Gender mentality and gender tolerance behavior improve the moral and psychological climate; increase the general culture in the security structures and ensure overall combat capability of the country as a whole.

\section{REFERENCES}

1. Krymets', L. V. (2016). Filosofiya vlady ta upravlinnya naukovo-osvitnim prostorom [Philosophy of power and management of scientific and educational space]. Kyiv: Zoloti vorota, 410.

2. Krymets', L. V, Pal'chyk, S. I. (2013). Aksiolohichni aspekty patriotyzmu v konteksti sotsial'noho upravlinnya [Axiological aspects of patriotism in the context of social governance]. Kyiv: Polihrafichniy tsentr NUOU, 250.

3. Saukh, P. Yu. (2012). Suchasna osvita: portret bez prykras [Modern education: a portrait without decoration]. Zhytomyr: Vyd-vo ZHDU im. I. Franka, 382.

4. Slepneva, O. Yu. (2006). Traditsii i transformatsii mentalnosti [Traditions and transformations of mentality]. Vestnik KGU im. N. A. Nekrasova, 11, 87-89.

5. Hamitov, N. (Ed.) (2016). Filosofskaya antropologiya [Philosophical Anthropology]. Kyiv: KNT, 472.

6. NATO Code of Conduct. Available at: https://www.nato.int/structur/recruit/infodoc/code-of-conduct.pdf

7. NATO 2017: BI-Strategic Command Directive (BI-SCD) 040-001 (INTEGRATING UNSCR 1325 AND GENDER PERSPECTIVE INTO THE NATO COMMAND STRUCTURE).

КРИМЕЦЬ, Л. В. - доктор філософських наук, старший науковий співробітник, провідний науковий співробітник науково-дослідної лабораторії (соціальногуманітарних проблем) кафедри суспільних наук Національного університету оборони України імені Івана Черняховського (Київ, Україна)

E-mail: Liudmylakrymets@ gmail.com ORCID 0000-0001-7451-5208

\section{ГЕНДЕРНИЙ ПІДХІД ТА ДЕМОКРАТИЧНІ ЦІННОСТІ У КОНТЕКСТІ ФОРМУВАННЯ МЕНТАЛЬНОСТІ СУЧАСНОГО ПОКОЛІННЯ ВІЙСЬКОВОСЛУЖБОВЦІВ}

Актуальність. Сучасне українське суспільство висуває набір професійних i морально-етичних вимог як для окремих військовослужбовців, так і для системи військово-професійної підготовки в цілому. У зв'язку з цим необхідно підготувати 
якісно новий управлінський персонал для військового управління та структур морально-психологічного забезпечення всіх рівнів. Певна підготовка необхідна для реалізації значного діапазону соціально-політичних і військових реформ в контексті демократизації та оптимізації української армії 3 урахуванням як кращого національного, так і провідного світового досвіду.

Мета статті - розкрити гендерний підхід і запропонувати визначення терміну ментальності військовослужбовців, а також продемонструвати деякі особливості процесу формування менталітету в Збройних Силах України. Методологічним підгрунтям дослідження $є$ загальні наукові принципи цілісності, об'єктивності i історизму, зв'язку теорії і практики; методи аналізу і систематизації, що дозволили виявити особливості формування ментальної культури військовослужбовців в процесі професійної підготовки.

Наукова новизна. Згідно авторської концепції, ментальність військовослужбовця являє собою систему, що динамічно розвивається, в якій відбувається зрощування не тільки особистісного, а й професійного розвитку. Ментальність військовослужбовців Збройних Сил України та інших складових сил оборони, визначається автором як інтегративна професійно-зумовлена соціокультурна властивість, що зумовлює специфіку їх світосприйняття, образ мислення, особливості формування колективної та індивідуальної свідомості та професійної поведінки. Гендерна ментальність - це соціально-етична складова ментальності військовослужбовця, яка розкриває специфіку гендерних стереотипів і спосіб мислення, що в умовах реформування і розвитку Збройних Сил України повинні грунтуватися на демократичних цінностях.

Висновок. Ця стаття допомагає зрозуміти, які демократичні цінності складають етичну основу для формування сучасної української армії, яка буде відповідати вимогам часу i розкриває специфіку формування гендерної менталітету військовослужбовців.

Ключові слова: ментальність військовослужбовців Збройних Сил України, гендерна ментальність, аксіологічні аспекти формування менталітету, етичний кодекс, європейські цінності, соціальна філософія, військове управління.

КРЫМЕЦ, Л. В. - доктор философских наук, старший научный сотрудник, ведущий научный сотрудник научно-исследовательской лаборатории (социальногуманитарных проблем) кафедры общественных наук Национального университета обороны Украины имени Ивана Черняховского (Киев, Украина)

E-mail: Liudmylakrymets@ gmail.com ORCID 0000-0001-7451-5208

\section{ГЕНДЕРНЫЙ ПОДХОД И ДЕМОКРАТИЧЕСКИЕ ЦЕННОСТИ В КОНТЕКСТЕ ФОРМИРОВАНИЯ МЕНТАЛЬНОСТИ СОВРЕМЕННОГО ПОКОЛЕНИЯ ВОЕННОСЛУЖАЩИХ}

Актуальность. Современное украинское общество выдвигает набор профессиональных и морально-этических требований как для отдельных военнослужащих, так и для системы военно-профессионального обучения в целом. В этой связи необходимо подготовить качественно новый управленческий персонал для военного управления и структур для морально-психологического обеспечения всех уровней. Определенная подготовка необходима для реализации значительного диапазона социально-политических и военных реформ в контексте демократизации и оптимизации украинской армии с учетом как лучшего национального, так и ведущего мирового опыта. Цель статьи - раскрыть гендерный подход и предложить определение термина ментальности современного военного персонала, а также продемонстрировать Gender approach and democratic values in the context of the modern generation of military staff's mentality shaping 
некоторые особенности процесса формирования менталитета в Вооруженных Силах Украины. Методологическим основанием исследования являются общие научные принципы целостности, объективности и историзма, связи теории и практики; методы анализа и систематизации, что позволило выявить особенности формирования ментальной культуры военнослужащих в процессе практического обучения. Научная новизна. По мнению автора, ментальность военнослужащего представляет собой динамично развивающуюся систему, в которой происходит сращивание не только личностного, но и профессионального опыта. Ментальность военнослужащих Вооруженных Сил Украины определяется автором как интегративное профессионально-обусловленное социокультурное качество, которое обуславливает специфику их мировосприятия, образ мышления, особенности формирования коллективного и индивидуального сознания и профессионального поведения. Гендерная ментальность - это социально-этическая составляющая ментальности военнослужащего, которая раскрывает специфику гендерных стереотипов и способ мышления, что в условиях реформирования и развития Вооруженных Сил Украины должны основываться на демократических ценностях. Заключение. Эта статья помогает понять, какие демократические ценности составляют этическую основу для формирования современной украинской армии, которая будет отвечать требованиям времени и раскрывает специфику формирования гендерного менталитета военнослужащих.

Ключевые слова: ментальность военнослужащих Вооруженных Сил Украины, гендерная ментальность, аксиологические аспекты формирования менталитета, этический кодекс, европейские ценности, социальная философия, военное управление.

Стаття рекомендована до публікачії д.філософ.н., проф. В.С. Білогур (Мелітополь, Украӥна)

Надійшла до редколегії: 15.09.2018

Прийнята до друку: 20.09.2018 